\title{
LEUCOPOGON COLLINUS (EPACRIDACEAE) AND ASSOCIATED TAXA IN TASMANIA
}

\author{
by J.M. Powell
}

(with four text-figures and two plates)

\begin{abstract}
Study of Tasmanian herbarium specimens currently under the name L. collinus (Labill.) R. Br. indicate that two other taxa are included with in it, namely $L$. pilifer Wakefield, known previously from Victoria, and $L$. oreophilus Powell sp. nov. A key to the three species is given and each is described. The history of the names, problems associated with early collections and the distinction of early varieties are discussed.
\end{abstract}

Key Words: Epacridaceae, flora, Tasmania.

In BANKS, M.R. et al. (Eds), 1991 (31:iii): ASPECTS OF TASMANIAN BOTANY - A TRIBUTE TO WINIFRED CURTIS. Roy. Soc. Tasm. Hobart: 105-112. https://doi.org/10.26749/rstpp.124.2.105

\section{INTRODUCTION}

Leucopogon collinus is a widespread common species in Tasmanian heathland vegetation and is found also in Victoria and New South Wales. In Tasmania it exhibits considerable morphological variation in leaf form and size, and in flower size. This led to a number of varietal, form and even other specific names being used by early botanists and collectors. More recently this species has been considered as a "complex" that requires further study. Curtis (1963) noted that "Although certain of the variants are very distinctive in appearance, intermediate forms occur and further work is necessary to determine their status."

Current study of herbarium specimens under this name indicates the presence of at least three taxa. One of these is Leucopogon pilifer Wakefield, described in 1956 from Victorian material and now recognised as also present in the central and northeastern mountains of Tasmania. Another, symparic with L. pilifer, is named in this contribution; it was illustrated and described as part of a variety of L. ciliatus Cunn. ex DC. distinguished by Hooker (1860) but not formally named. $L$, collinus is retained as a morphologically complex species with apparently continuous variation in a number of attributes. Future field studies of populations and morphometric analysis may lead to a number of taxa being distinguished within this complex but this has not been possible on the basis of the herbarium material currently available.

\section{EARLY NAMES AND SPECIMENS OF L. COLLINUS AND L. CILIATUS}

\section{Leucopogon collinus (Labill.) R.Br.}

Leucopogon collinus was described originally by Labillardière (1804-6) as Styphelia collina from specimens collected in the Storm Bay area (labelled "Capite Van-Dieman") according to Nelson (1974). Labillardière described the plant as a foot [0.3 m] high, with the leaves scattered, reddish when young and flat, oblong, sessile, and serrate-ciliate. The flowers were borne on simple or paired oblong racemes, often terminal, and the calyx and bracts were 5-7 nerved. The anthers were attached at the middle. The ovary was ovate, the style short, and the hypogynous disc had 5 somewhat acute scales. The drupe was 5-locular, ovateoblong, with a solitary seed developing.

Labillardière's diagram (1804: 47, tab. 65) shows flat, narrow-elliptic leaves, 6-9-flowered spikes and the drupe 2-locular with three other vascular bundles possibly indicating aborted locules. Specimens labelled as from his collections held at K, MEL and in the De Candolle Herbarium match well with the diagram. Study of the $\mathrm{K}$ and MEL material indicates that the ovary is 2-locular, not 5-locular as stated.

Brown (1810) described $L$. collinus from his own specimens collected from heathlands near Port Dalrymple and the Derwent River (Bennett 2442 at $\mathrm{K}$ !). He noted that the spikes terminated short lateral branches, and that the leaves were oblong-linear, slightly acute, blunt, erect, smooth, slightly convex, the margin recurved, denticulate. He placed S. collina Labill. in synonymy. 

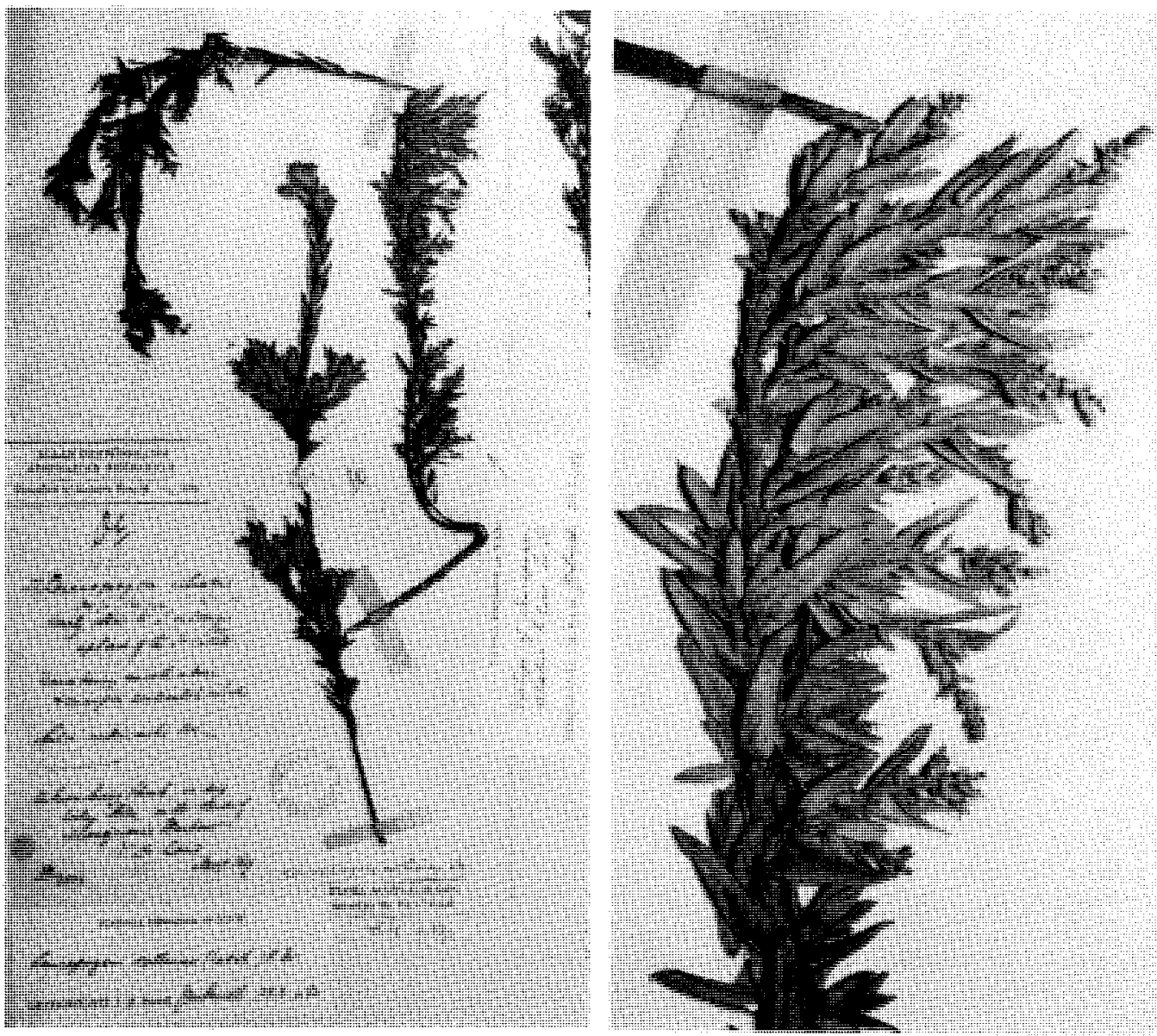

PLATE 1

(A) Isotype collection of Leucopogon ciliatus Cunn. ex DC. (B) Close-up of part of this specimen showing characteristic Leucopogon collinus attributes of recurved leaf margins, and multiflowered spikes exceeding leaves.

The leaves of Brown's specimens are mainly oblong or sometimes elliptic and the spikes are 8-17-flowered.

De Candolle (1839) accepted both of the earlier descriptions and distinguished two varieties:

$-\alpha$, billardieri, based on the Labillardière specimen which he noted as having flat leaves that were ciliate over their whole length;

- $\beta$, brownii, based on Brown's specimen from Port Dalrymple, characterised by having leaves with recurved margins that were ciliate-denticulate in both directions.

Hooker (1860) distinguished three varieties of $L$. collinus on the basis of plant height, leaf length, shape and disposition and type of margin. He cited various Gunn specimens as typical of each and placed De Candolle's variety brownii and $S$. collina Labill. in synonymy.

Study of all the specimens listed by Hooker for his three varieties ( var. $\alpha$ : Gunn 1191, Gunn 211, Gunn 34 ; var. $\beta$ : Gunn 1190; and var. $\gamma$ : Gunn 1188, Gunn 1189 ), indicate that they all belong within $L$. collinus. These specimens show some variation in leaf shape, in length and width, density of marginal teeth and recurving of the margin, and in calyx shape and marginal hairiness, but there are no obvious disjunctions in the variation, or other attributes that can be used as a basis for differentiation. 


\section{Leucopogon ciliatus Cunn. ex DC.}

De Candolle (1839) published Allan Cunningham's manuscript name Leucopogon ciliatus based on a Cunningham specimen collected on the west coast of Tasmania. This specimen appears to be a duplicate of that held at Kew which has the number 80/1819 and additional information "A branching shrub on dry rocky hills, on the shores of Macquarie Harbour V.D Land January 1819 " (pl. 1A, B). The plant was described by De Candolle as having crowded, puberulous branchlets, with the leaves linear-oblong with blunt apex, $6-8 \mathrm{~mm}$ long, fairly flat, ciliate and glabrous both sides. The spikes were terminal, 8-10 mm long, almost solitary, slightly longer than the leaves, 9-10-flowered, with the peduncle puberulent. The flowers were dense, the corolla lobes very hirsute above.

The specimens appear to be typical of a robust form of $L$. collinus that has dense, convex, relatively short leaves, and many-flowered spikes that exceed the leaves (pl. 1B).

On the label, Cunningham commented that the species was "closely allied to L. villosus R.Br. a plant of the So. Coast" but De Candolle (1839) noted that that particular species was unknown to him. L. villosus $\mathrm{R}$. Br. is part of a Western Australian species complex currently considered under the name L. obovatus (Labill.) R.Br. or L.revolutus R.Br.

Hooker accepted L. ciliatus although he noted that it "may be a variety" of L. collinus (Hooker 1860: 251). He described it as a small shrub, the branches sub-erect or decumbent, the leaves small, elliptical or oblongelliptic, acuminate, blunt-tipped, flat, glabrous and ciliate, and the spikes sub-solitary, terminal, and 4-8-flowered. He considered that De Candolle's L. petiolaris, L. collinus var. $\alpha$, billardieri and Labillardière's Styphelia collina were possibly synonyms.

Hooker (1860) distinguished two varieties of L. ciliatus :

- var. $\alpha$, described as robust, with erect branches and many flowered spikes; based on Gunn 852 and Gunn 1191 collections, this variety was "not uncommon in various parts of the colony"; other specimens, collected by A. Cunningham, Bynoe, Milligan, and Gunn were also cited.

- var. $\beta$ described as smaller, with slender, short, decumbent branches, the leaves elliptic-ovate, occasionally with long cilia, and the spikes short, fewflowered; based on Gunn 1192, Gunn 1984 and Gunn 2048 , this variety was illustrated as tabula $75 \mathrm{~A}$ (Hooker 1860); it was found in "Alpine situations, Chilton Hills, Lake StClair, Surry Hills, summit of Western Mountains etc., Gunn - (Fl. Oct.-Dec.)".
Study of the variety $\alpha$ specimens indicate that they are L. collinus and confirms that L. ciliatus Cunn. ex $D C$. is synonymous. The materials listed under variety $\beta$ are different and there are two taxa included within this variety: Gunn 1192 is, in fact, L. pilifer Wakefield, characterised by long cilia on the leaf margins; it is described in detail below. The specimens numbered Gunn 1984 and Gunn 2048 both have short, broadly elliptic leaves that are concave or flat, with marginal cilia much shorter than in L. pilifer and finer and more evenly spaced than in most specimens of $L$. collinus. This is the taxon illustrated in Hooker's tabula 75A and now described in detail and designated as a new species.

L. petiolaris DC, placed in synonymy by Hooker, is Cyathodes petiolaris (DC.) Druce.

Bentham (1869) included L. ciliatus Cunn. ex DC. in L. collinus (Labill.) R.Br. He stated:

"The commonest form in Tasmania is erect, shrubby, and slightly pubescent. From mountain grassy situations the specimens show a small diffuse plant with slender branches and small almost flat leaves. Cunningham's specimens of L. ciliatus have more the habit and longer leaves of the common form, but they are nearly flat. They answer very well to Labillardière's own specimens."

Bentham's concept is obviously a broad one, including within $L$. collinus both $L$. pilifer and the new species.

\section{Leucopogon pilifer Wakefield}

This taxon, described by Wakefield (1956) as Leucopogon piliferus (grammatically incorrect pilifer = bearing hairs), is based on a Willis specimen as holotype, but in the notes, specimens collected by $\mathrm{F}$. Mueller are mentioned as variously labelled as $L$. collinus b. alpinus and S. alpinus (see MEL 78512, MEL 78502). Mueller (1867-68) did not formally name these taxa; he mentioned them under Styphelia collina stating

"in the highest alps of Australia and Tasmania a beautiful small tufted form barely $11 / 2$ inches [38 mm] high, nevertheless with abundant flowers, occurs. Here I would place L. ciliatum (A. Cunn. in Cand. Pr. vii. 746). A variety pubescent overall has been collected in the Victorian Ranges. The alpine form everywhere we see to have solitary flowers and often smaller leaves and flowers, decumbent stems" [author's translation]. 


\section{KEY TO THE TAXA}

1. Plant erect, usually $0.3-0.6 \mathrm{~m}$ but up to $1 \mathrm{~m}$ high; leaf shape varying considerably on a single plant from ovate to oblong to elliptic or combinations of these; leaf margin varying from entire to coarsely denticulate-ciliate

L. collinus

1. Plant diffuse or prostrate, often forming mats with branches to $0.1 \mathrm{~m}$ long; leaves relatively constant in shape on a single plant, elliptic or oblongelliptic; leaf margin either long-ciliate or shortly and evenly ciliate-denticulate.................. 2

2. Leaf margin ciliate-denticulate; branchlets scabrous to hispid; flowers in terminal spikes, with 3-6 flowers/spike; fruit apex rounded with persistent style-base................. oreophilus

2. Leaf margin long-ciliate; branchlets sericeous; flowers in terminal and upper axillary spikes, with 4-9 flowers/spike; fruit flat-topped or apically depressed L. pilifer

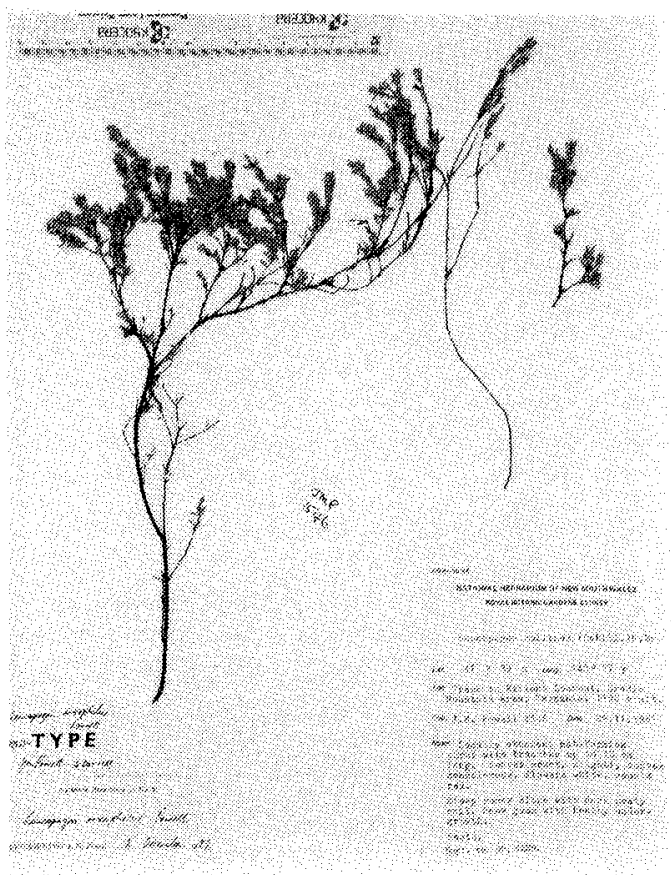

PLATE 2

Holotype: Leucopogon oreophilus Powell.

\section{TAXONOMY}

\section{Leucopogon oreophilus Powell, sp. nov. \\ ( pl. 2, fig. 1)}

Leucopogon oreophilus Powell; L. collino affinis sed differt: habitu diffuso, saepe tegetes formanti; foliis brevioribus et planis; spicis terminalibus, paucifloris, foliis ex parte occultis.

\section{Typus}

Holotype: Tasmania: Cradle Mountain area, track to Marions Lookout, 41 ${ }^{\circ} 39^{\prime}$ S $145^{\circ} 57^{\prime} \mathrm{E}, 1100 \mathrm{~m}$ a.s.l., J.M. Powell 1546, 29.xi.1981 (NSW, pl. 2). Isotypes: HO, CANB.

\section{Variants Included}

L. ciliatus var. $\beta$ of Hooker (1860) in part. Hooker's tabula 75A, based on Gunn 1984 (K, NSW 223220) and Gunn 2048 (K, NSW 223219) illustrates this species.

\section{Description}

A prostrate or diffuse mat-forming shrub with branches up to $0.1 \mathrm{~m}$ long. Stems spreading to erect, dark brown, more or less glabrous; branchlets yellow- to red-brown, scabrid to hispid. Leaves crowded towards the branch tips, erect, broadly and shortly elliptic, $2.7-6.3 \mathrm{~mm}$ long, 1.2-2.2 mm wide (length:width $=1.7-3.9: 1$ ); apex broadly acute, concave above, with a very small callus on abaxial surface; base tapering to a $0.3-0.6 \mathrm{~mm}$ long petiolar area; lamina thick, usually flat, concolorous, glabrous; venation inconspicuous above or occasionally the midrib sunken towards the base, and with three equal sub-parallel veins obvious below, the outermost branching to the margin; margins shortly and evenly ciliolate or sometimes more coarsely so. Flowers inconspicuous, partly hidden by the leaves, erect, white, borne in terminal spikes on short shoots; spikes 2-6 mm long, usually with $3-6$ flowers per spike, and a bud-like rudiment at the apex. Peduncles hispid. Bracts and bracteoles ovate, broadly acute, glabrous except for the ciliolate margins; bracts scarious, uniform in size, $0.8-0.9 \mathrm{~mm}$ long, $0.6-0.8 \mathrm{~mm}$ wide, striate-veined; bracteoles $0.9-1.2 \mathrm{~mm}$ long, $0.5-1.0 \mathrm{~mm}$ wide, keeled. Sepals oblong, 1.3-1.7 mm long, 0.5$1.0 \mathrm{~mm}$ wide, broadly acute or sometimes obtuse, the midrib thickened at the apex, glabrous except for the ciliolate margins. Corolla:tube shorter than the sepals, very broadly U-shaped, $0.7-1.2 \mathrm{~mm}$ long, $0.9-1.7 \mathrm{~mm}$ wide at the throat, glabrous; lobes longer than the tube (lobe length:tube length $=1.1-1.8: 1$ ), erect at the base, spreading or recurved above, 0.9-1.3 mm long, 0.6$0.9 \mathrm{~mm}$ wide, acute or broadly acute, externally glabrous, internally bearded overall with the hairs on the upper half long and dense, on the lower half sparser and much shorter. Anthers half-exserted, 0.6-0.9 mm 

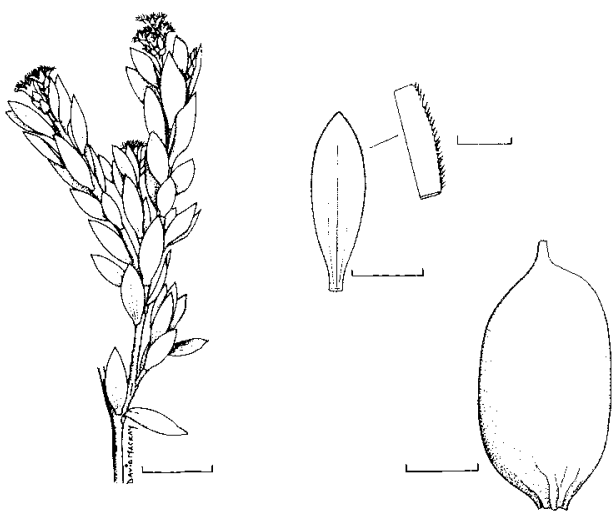

FIG.I-Leucopogon oreophilus Powell showing habit $($ scale $=5 \mathrm{~mm})$, leaf $($ scale $=2 \mathrm{~mm})$ and margin (scale $=0.5 \mathrm{~mm}$; all from holotype) and fruit (scale $=0.5 \mathrm{~mm}$; specimen Gordon, $\mathrm{HO} 3554$ ).

long, with $0.1-0.2 \mathrm{~mm}$ long sterile tips; filaments 0.1 $0.35 \mathrm{~mm}$ long, attached above the middle. Ovary usually spherical, $0.3-0.5 \mathrm{~mm}$ diam., slightly lobed, glabrous, 2-celled; style 0.15-0.2 mm long, cone-shaped at the base, not exserted from the corolla tube; stigma c. $0.1 \mathrm{~mm}$ high; nectary annular, lobed, $0.25-0.3 \mathrm{~mm}$ high, glabrous. Fruit just exceeding calyx, oblong, $2.2 \mathrm{~mm}$ high, $1 \mathrm{~mm}$ wide, somewhat compressed laterally, smooth or two-lobed, glabrous, with rounded apex, the style-base apparently persistent.

\section{Derivation of Name}

The specific epithet "oreophilus" (Greek = mountainloving) refers to the habitat of this species.

\section{Distribution and Ecology}

Recorded mainly from high altitudes $(>950 \mathrm{~m})$ in the Cradle Mountain area, but also from West Coast and South West ranges (fig. 4). Occurs in heath associations on rocky slopes with peaty soil, or in rock crevices with skeletal wet soils. The species flowers between November and February, with fruit recorded in January.

\section{Variation}

This species appears to be relatively uniform in leaf shape and size compared with $L$. collinus, and is prostrate and mat-forming in habit. Eighteen specimens were examined (full list available from the author); one, collected from west of Granite Tor, Central Highlands (Moscal 9451), has a more robust, densely twiggy and apparently erect habit, and in leaf and floral attributes is at the upper extreme of the L. oreophilus range; its

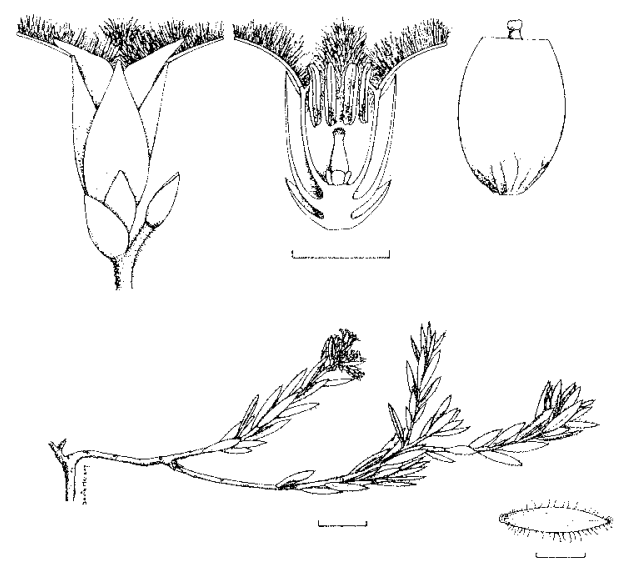

FIG. 2 -Leucopogon pilifer Wakefield showing habit (scale $=5 \mathrm{~mm})$, leaf $($ scale $=2 \mathrm{~mm})$, terminal flower, flower section and fruit (all at scale $=I \mathrm{~mm}$; all from specimen J. M. Powell 1543).

status may require reassessment after further field studies.

\section{Selected Specimens Examined}

Central Highlands (6) (regions as Orchard 1988) Comber 2163 (K); Gordon s.n. (HO 3554). West Coast (5) - Jackson (HO 90298). South West (10) - Moscal 9377 (HO 95150); Elliott s.n. (HO 3551). [Further details of specimens listed in this paper, e.g. collecting site and date, are available from the Herbaria noted or from the Royal Society of Tasmania Library (Archives), GPO Box 1166M, Hobart, Tasmania, Australia 7001.]

\section{Leucopogon pilifer Wakefield} (fig. 2)

\section{Typus}

Holotype: Head of Wild Horse Creek, Bogong High Plains, northeast Victoria, near Kellys Hut, c. $1500 \mathrm{~m}$ a.s.l., J. H. Willis, s.n. 19.i.1947 (MEL 68482).

\section{Variants Included}

L. ciliatus Cunn ex. DC. var. $\beta$ Hooker (1860) in part, based on Gunn 1192 (K, NSW 223228).

\section{Description}

A dwarf, diffuse, often mat-forming shrub, with branches $0.02-0.1 \mathrm{~m}$ long. Stems spreading, red-brown, densely to sparsely sericeous; branchlets yellow- to red-brown, smooth, sericeous. Leaves erect to sub-erect, usually oblong or elliptic, sometimes oblong-elliptic, 
or rarely ovate, $3.1-5.4(-7.3) \mathrm{mm}$ long, $0.7-1.3 \mathrm{~mm}$ wide (length:width $=2.86(-6.5): 1$ ); apex acute, concave above, with a callus on abaxial surface; base tapering to a petiolar area $0.3-0.5 \mathrm{~mm}$ long; lamina thin, flat or slightly convex abaxially, concolorous, glabrous; venation inconspicuous above except for the midrib sunken over at least the lower half, below with 3-5 sub-parallel equal veins obvious; margins straight or slightly recurved, with long silky hairs scattered towards the apex or overall, particularly obvious in the young growth. Flowers inconspicuous, erect, white, star-shaped, borne in terminal and uppermost axillary spikes 3-6 mm long, usually with 4-9 flowers per spike and a bud-like rudiment at the apex. Peduncles pubescent. Bracts and bracteoles ovate, acute, glabrous except for the ciliolate margins; bracts scarious, uniform in size, $0.9-1 \mathrm{~mm}$ long, $0.6-0.9 \mathrm{~mm}$ wide, striateveined; bracteoles $0.9-1 \mathrm{~mm}$ long, $0.7-0.8 \mathrm{~mm}$ wide, keeled. Sepals triangular to ovate, $1.4-1.6 \mathrm{~mm}$ long, $0.8-0.9 \mathrm{~mm}$ wide, acute, striate-veined, the midrib thickened somewhat towards the apex, glabrous except for the ciliolate margins. Corolla: tube shorter than the sepals, narrow, 0.9-1.2 mm long, 0.7-0.8 mm wide, glabrous externally, pubescent inside to the base of the anthers; lobes shorter or equal to the tube (lobe length:tube length $=0.08-1: 1$ ), spreading, $1-1: 2 \mathrm{~mm}$ long, $0.35-0.4 \mathrm{~mm}$ wide, acute, externally glabrous, internally densely bearded with long hairs. Anthers $0.6-0.7 \mathrm{~mm}$ long, with $0.1 \mathrm{~mm}$ long sterile tips; filaments c. $0.15 \mathrm{~mm}$ long, attached above the middle. Ovary ovoid, $0.3 \mathrm{~mm}$ high, $0.25 \mathrm{~mm}$ wide, somewhat lobed, glabrous, 3-celled; style $0.2 \mathrm{~mm}$ long, not exserted from the corolla tube; stigma $0.05-0.1 \mathrm{~mm}$ high; nectary annular, lobed, $0.15-0.2 \mathrm{~mm}$ high, glabrous. Fruit greatly exceeding the calyx, oblong, 1.5-2 mm high, $1-1.1 \mathrm{~mm}$ wide, apically depressed, slightly ridged, glabrous, with the style apparently persistent.

\section{Distribution and Ecology}

Found in Tasmania mainly in the Central Highlands (fig. 4) at altitudes above $600 \mathrm{~m}$ forming patches on wet peaty soil in subalpine heath-shrubbery, in rock crevices on steep slopes, below snow gums on bouldery plains with yellow clayey soils. In Victoria found on the high plains of East Gippsland, and in New South Wales at Barrington Tops in the Northern Tablelands. Flowers November-December, with fruit in January, young buds in May.

\section{Variation}

Little variation is exhibited by this species despite its wide distribution. Twenty-five specimens were studied (full list available from the author); the Victorian specimens have somewhat longer leaves and denser cilia on the margins compared with the Tasmanian material, while the New South Wales collections have only sparse cilia.

\section{Selected Specimens Examined}

Tasmania: Ben Lomond (8) - K.J. Williams \& J. Grant s.n. (HO 116315). Central Highlands (6) - S. J. Jarman \& R. K. Crowden s.n. ( HO 111464); J.M. Powell 1543 (NSW, HO).

Victoria: East Gippsland - J. H. Willis s.n. (MEL 502549); P. K. Gullan 238 (MEL 528711 ).

New South Wales: Northern Tablelands - R. Story 7535 (CANB, NSW); P. Burgess 52 (NSW).

\section{Leucopogon collinus (Labill.) R.Br. (fig. 3)}

\section{Basionym \\ Styphelia collina Labillardière (1804).}

\section{Type}

Tabula 65 in Labillardière Pl. Nov. Holl. i. 47 (1804). Lectotype being investigated.

\section{Synonyms}

L. collinus (Labill.) R.Br. var. $\alpha$, billardieri DC. Prod. 7.748 (1839), based on the Labillardiere specimen (?syntype) held in the De Candolle Herbarium. L. collinus (Labill.) R. Br. var. brownii DC. Prod. 7.748 (1839), based on a specimen collected by Robert Brown (with the legend in his handwriting) "Leucopogon collinus prodr 543 Port Dalrymple" held in the De Candolle herbarium, here designated as lectotype. L. ciliatus Cunn. ex DC. Prod. 7.748 (1839), based on Cunningham specimen held in De Candolle herbarium (with the legend in Cunningham's handwriting) "Leucopogon ciliatus C. closely allied to L. villosus Br. W coast of Van Diemans Land Jan 1819 AC.", here designated as lectotype.

\section{Variants Included}

L. collinus vars $\alpha, \beta$, $\gamma$ of Hooker (1860), based on var. $\alpha$ - Gunn 1191 (NSW 223384), Gunn 211 (K), Gunn 34 (K, NSW 223233, BM); var. $\beta$ - Gunn 1190 (K, NSW 223386, BM); and var. $\gamma$ - Gunn 1188 (NSW 223396, K, BM), Gunn 1189 (K). L. ciliatus Cunn. ex DC. var. $\alpha$ of Hooker (1860) based on Gunn 852 (NSW 223378,223379 ) and Gunn 1191 (K, NSW 223380, 223384).

\section{Description}

An erect, slender or compact shrub, 0.3-1 m high, 0.1$0.3 \mathrm{~m}$ across. Stems dark red- to grey-brown, glabrous or scabrous; branchlets red-brown, scabrous to hispid. Leaves erect to sub-erect, variable in shape on a single plant, some being ovate, oblong or elliptic, or 
combinations of these, $3-13.4 \mathrm{~mm}$ long, $0.9-2.7 \mathrm{~mm}$ wide (length: width $=2.2-8.7(-11.2): 1$ ); apex acute to broadly acute, concave above, often slightly recurved, with a callus; base broadly tapering to a petiolar area 0.3-1 mm long; lamina usually convex abaxially, sometimes flat, concolorous or somewhat paler below, glabrous or sc abrous towards the base above; venation inconspicuous above, usually with the midrib sunken overall or over the lower half, faintly striate below; margins usually recurved, sometimes entire but usually coarsely ciliate-denticulate towards the apex if not overall. Inflorescences usually terminal and upper axillary, often forming leafy clusters up to $20 \mathrm{~mm}$ long and wide, over-topping the leaves, sometimes terminal only on short shoots; single spikes usually $5-13 \mathrm{~mm}$ long, with $10-29$ (rarely 7 or less) flowers per spike and a bud-like rudiment at the apex. Flowers white, the buds often pink-tipped. Peduncles scabrous. Bracts scarious or rarely more leaf-like, ovate-oblong, 0.7-1.7 mm long, $0.5-1.0 \mathrm{~mm}$ wide, broadly acute or obtuse, striateveined, glabrous, with ciliolate margins. Bracteoles ovate, $0.7-1.7 \mathrm{~mm}$ long, $0.6-1.0 \mathrm{~mm}$ wide, broadly acute or obtuse, keeled, glabrous, with ciliolate margins and often with a tuft of longer hairs at the apex. Sepals ovate-oblong, often reddish distally, 1.3-1.9 mm long, $0.6-1.0 \mathrm{~mm}$ wide, broadly acute, the midrib thickened at the apex, glabrous, with the margins ciliolate or often ciliate towards the apex. Corolla: tube shorter than the sepals, U-shaped, 0.8-1.4 mm long, 1.1-1.3 mm wide at the throat, glabrous externally, sparsely pubescent inside to the base of the anthers; lobes usually longer than the tube (lobe length:tube length $=(0.9)-1.1-1.8: 1$ ), erect to spreading, $1.3-1.6 \mathrm{~mm}$ long, $0.5-0.55 \mathrm{~mm}$ wide, broadly acute, externally glabrous, internally densely bearded with the hairs longer over the upper half of the lobe. Anthers 0.7-1.0 mm long, with $0.15-0.25 \mathrm{~mm}$ long sterile tips; filaments $0.2-0.5 \mathrm{~mm}$ long, attached above the middle. Ovary spherical to somewhat ovoid, $0.35-0.45 \mathrm{~mm}$ diam., smooth to slightly lobed, glabrous, 2-celled; style cone-shaped at the base, $0.2-0.3 \mathrm{~mm}$ long, not exserted from the corolla tube; stigma 0.05 $0.1 \mathrm{~mm}$ high; nectary annular, lobed, $0.1-0.3 \mathrm{~mm}$ high, glabrous. Fruit greatly exceeding the calyx, oblong, $2.35-2.5 \mathrm{~mm}$ high, $0.85-1.4 \mathrm{~mm}$ wide, tapering apically with persistent style, ribbed or slightly ridged, glabrous.

\section{Variation}

As the morphological variation exhibited was considerable and there appeared to be specimens intermediate between $L$. oreophilus and $L$. collinus, detailed study of 66 Tasmanian specimens from six botanical-geographic regions was undertaken. The results confirmed the continuous nature of the variation in leaf shape, size and margin structure and in inflorescence length and flower numbers in $L$. collinus

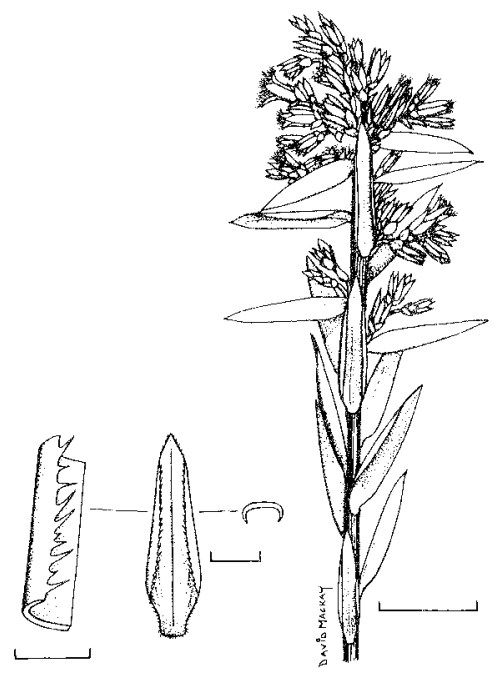

FIG. 3 - Leucopogon collinus (Labill.) R. Br. showing habit (scale $=5 \mathrm{~mm}$; specimen J. Armstrong 886), leaf and transverse section (scale $=2 \mathrm{~mm}$ ) and margin (scale $=0.5 \mathrm{~mm}$; specimen S. G. Hannaford NSW 223623).

and, although some slight trend towards flatter leaves and shorter spike lengths appeared with the West Coast specimens, no significant differences were found. Some specimens from the West Coast and South West regions, namely Moscal 5028 (Mt Frankland, 19.xii.1988, HO 111211), Moscal 4922 (Mt Balfour, 17.xii.1983, HO 77123) and Brown $37 \mathrm{l}$ (Cox Bight, Pt Eric, 23.iii.1984, HO 78576), Collier 2221 (The Coronets, 24.i.1987, HO 103910), Willis MEL 526752 (western slopes of Mt Eliza, 04.i.1977) and Milligan 807 (Birchs Inlet Mountain Range, 25.xi.1846, HO 3561) respectively, show similarities to $L$. oreophilus in some attributes, but in all cases they fall within the range of $L$. collinus on the basis of leaf shape (leaf length:width ratios), and also most have somewhat longer spikes and more flowers/spike than recorded for $L$. oreophilus, and appear to be erect in habit. Further field studies may suggest some reassessment of the limits of these two taxa.

\section{Distribution and Ecology}

In Tasmania widespread (fig. 4) and common in sandy coastal heathlands and scrub, and in the heathy understorey of low altitude dry sclerophyll woodlands. Flowers through most of the year (except June-July), with the fruit developing rapidly. In Victoria found in East Gippsland and in New South Wales restricted to the southernmost parts of the South Coast. 


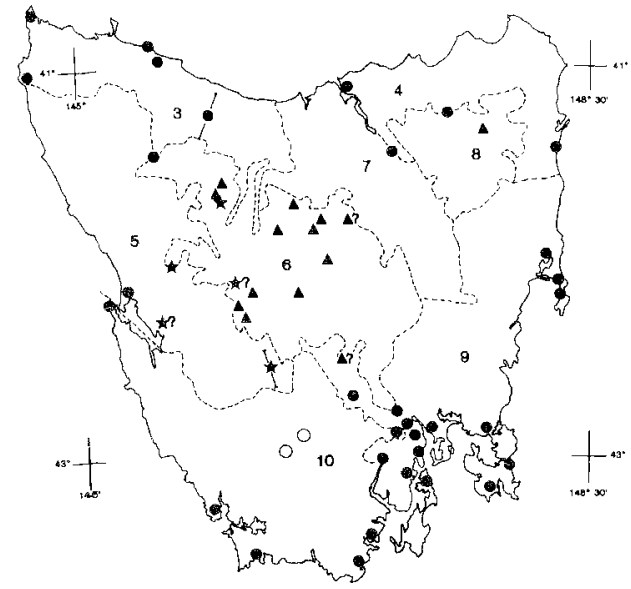

FIG. 4-Distribution of three species in Tasmania. L. collinus, L. pilifer, L. oreophilus, indet. ?L. collinus. Bars or query next to the symbol indicate an imprecise locality record. Natural region numbers and boundaries (shown dashed) follow Orchard (1988) except that region 10 (South West) here includes the small regions 11 (Mt Field) and 12 (Mt Wellington). Names of the regions, here indicated by numerals, are given under "Specimens Examined".

\section{Selected Tasmanian Specimens Examined}

North West (3) - K. L. Wilson 6396 (NSW); J.M. Powell 1582, 1588 (NSW). West Coast (5) - K.L. Wilson 6327 (NSW); R.H. Cambage 2561 (NSW 223230). South West (10) - M. Davis 1267 (HO 3552, MEL 75787); Giblin s.n. (HO 3566). South East (9) I. Olsen 123 (NSW); J.M. Powell 544, 545 (NSW). North East (4) - N.T. Burbidge 3060 (CANB, HO 3588); W.M. Curtis s.n. (HO 3560, HO 3561). Midlands (7) - Hamilton 32 (HO 3595); S.G. Hannaford herb (NSW 223235).

\section{RELATIONSHIPS}

$L$. oreophilus and $L$. collinus, although very closely related, differ in a number of attributes in their typical form - in habit, in the range of leaf shape shown on individual plants (reflected clearly in the mean and range of leaf length:width ratios), in thickness of the lamina and usually in the structure of the leaf margin. The flowering spikes appear to be always terminal in $L$. oreophilus; they are shorter and fewer flowered than in L. collinus and the flowers differ somewhat in shape and size of the calyx parts, in the corolla lobes, anthers and fruit. $L$. oreophilus occupies high altitude areas and has a relatively short flowering season, while $L$. collinus is widespread in coastal and lower altitude heathlands and flowers throughout the year.

$L$. pilifer shares with $L$. oreophilus the high altitude areas of Tasmania, and has a similar growth-form and also short, few-flowered inflorescences. It is strikingly different, however, from both $L$. oreophilus and $L$. collinus in having long silky hairs on the leaf margin and sericeous branchlets. It differs also in having narrower, oblong leaves, and flowers that have more acute calyx parts, a narrow corolla tube and corolla lobes shorter or equal to the tube; the fruit differs in being depressed apically.

\section{ACKNOWLEDGEMENTS}

I should like to thank Jean Jarman for checking recent specimens at the Tasmanian Herbarium for me, and. Tony Orchard for forwarding a loan of these at short notice to NSW. Thanks also to Dr Mary Tindale for assistance with the Latin diagnosis and helpful comments on the draft manuscript, to Surrey Jacobs for photography at Kew, and to David Mackay and Bob Makinson for assistance with the diagrams.

\section{REFERENCES}

Bentham, G., 1869: FLORA AUSTRALIENSIS: A DESCRIPTION OF THE PLANTS OF THE AUSTRALIAN TERRITORY, VOL. 4. Reeve, London.

Brown, R., 1810: PRODROMUS FLORAE NOVAE HOLLANDIAE ET INSULAE VAN-DIEMEN. Taylor, London.

CurTIS, W. M., 1963: THE STUDENT'S FLORA OF TASMANIA, PART 2. Government Printer, Tasmania.

de Candolle, A. P., 1839: PRODROMUS SYSTEMATIS NATURALIS REGNI VEGETABILIS, VOL. 7. Treuttel \& Wurtz, Paris.

HoOKER, J. D., 1860: THE BOTANY OF THE ANTARCTIC VOYAGE OF H. M. SHIPS "EREBUS" AND "TERROR", IN THE YEARS 1839-1843. VOL. 3. FLORAE TASMANIAE. Reeve, London.

LABILLARDIERE, J.J.H. DE, 1804-6: NOVAE HOLLANDIAE PLANTARUM SPECIMEN. Huzard, Paris.

Múeller, F. J. H. von, 1867-68: FRAGMENTA PHYTOGRAPHIAE AUSTRALIAE, VOL. 6. Ferres, Melbourne.

Nelson, E. C., 1974: The locations of collections and collectors of specimens described by Labillardière in NOVAE HOLLANDIAE PLANTARUM SPECIMEN - additional notes. Pap.Proc. R. Soc. Tasm. 108: 159-170.

OrCHard, A. E., 1988: A natural regions map for Tasmania. Pap. Proc. R. Soc. Tasm. 122: 47-51.

WakeField, N. A., 1956: Flora of Victoria: New species and other additions - 8. Vict. Nat. 73: 58-60.

(accepted 4 May 1990) 